\title{
Clinicopathologic study of E-cadherin/beta- catenin complex, and topoisomerase-II in a series of 71 liposarcoma cases
}

Pinelopi Gogou', Emilios Pakos ${ }^{1}$, Anna Batistatou², loannis Panelos ${ }^{2}$, Evangelos Briasoulis ${ }^{4}$, Dimitrios Stefanou ${ }^{2}$, Nikoforos Apostolikas ${ }^{3}$ and Periclis Tsekeris ${ }^{1,4^{*}}$

\begin{abstract}
Background: To investigate the expression of E-cadherin, beta-catenin and topoisomerase-II alpha and examine their clinical relevance in liposarcomas.

Materials and methods: The expression of E-cadherin, beta-catenin and topoisomerase II alpha was examined immunohistochemically on formalin-fixed paraffin-embedded tissue specimens from 71 patients who underwent surgical treatment for liposarcomas of the extremities or the retroperitoneum in two major cancer reference centres between 1990 and 2000. Detailed medical notes were available for all patients who were followed for median 82 months (range 5 to 215 months). Obtained expression data were weighted against clinical and pathology parameters of clinical relevance.
\end{abstract}

Results: Patients were mostly male (59\%), median age was 56 years for the liposarcomas of the extremities and 60 years for the retroperitoneal liposarcomas. The tumours were of diverse histology, grade and size (median diameters 7 and $17 \mathrm{~cm}$ for tumours of the extremities and retroperitoneum respectively). Expression of $\beta$-catenin protein was weakly detected in 15 cases (21.1\%). Similarly weak expression of topoisomerase II-alpha was detected in $14(19.7 \%)$ cases of which only two had more than $20 \%$ of tumor cells stained positive. E-cadherin was not detected in the studied cohort of liposarcomas. We did not detect associations between the expression of the above proteins by liposarcoma cells and clinical outcome.

Conclusions: Liposarcomas do not express E-cadherin, which matches the absence of epithelioid differentiation in this sarcoma subtype, and have low topoisomerase II-alpha expression, which justifies to some extend their resistance to anthracycline-based chemotherapy.

Keywords: liposarcomas, E-cadherin, b-catenin, topoisomerase II alpha, prognosis

\section{Background}

Liposarcomas are the most common subtype of soft tissue sarcomas (STS) accounting for approximately $20 \%$ of all STS in adults [1,2]. The World Health Organization Committee classifies them in 5 subtypes according to the degree of differentiation [3]. Despite the fact that each histological subtype has a different clinical behavior and disease outcome, treatment is common for all liposarcoma subtypes and consists of wide resection of the

\footnotetext{
* Correspondence: ptsekeri@cc.uoi.gr

'Department of Radiation Oncology, University loannina, Medical School,

Stavrou Niarhou Av 1., 45500 Ioannina, Greece

Full list of author information is available at the end of the article
}

tumor followed by additional radiotherapy and occasionally chemotherapy $[4,5]$. Although genetic tests have emerged in liposarcomas, still limited data exist regarding molecular profiling of these common STS subtypes [6].

The expression of E-cadherin/beta-catenin complex has been investigated in several tumors including STS [7]. The E-cadherin/beta-catenin complex is formed at cell-to-cell junctions and it is known to be involved in the wingless/Wnt signal transduction pathway. Wnt halts phosphorylation-degradation of the beta-catenin protein, which is consecutively accumulated in the cytoplasm and translocated to the nucleus where it functions

\section{Biomed Central}


as a transcription co-activator of several genes in involved in cell proliferation $[8,9]$. Interestingly, reduced expression of the E-cadherin/beta-catenin complex has been associated with aggressive tumor features such as poor differentiation, infiltrative growth, metastatic potential and short patient survival in several cancer types $[10,11]$. The DNA topoisomerase-II-alpha (TOP2 $\alpha$ ) is one of the major nuclear proteins with peak expression at $\mathrm{G} 2 / \mathrm{M}$ phase. It is virtually involved in every aspect of DNA metabolism, playing an important role in chromosome organization and segregation [12]. This cellular molecule is considered a key modulator of anticancer activity of anthracycline drugs $[13,14]$.

In the present study we evaluated the expression of Ecadherin, beta-catenin and TOP $2 \alpha$ proteins in a series of 71 liposarcoma cases and investigated potential associations of these molecules with clinical outcome.

\section{Methods}

Formalin-fixed paraffin-embedded tissue specimens from patients who had undergone surgical treatment for liposarcomas for whom detailed medical notes and adequate follow up records were made available, were selected for this study.

Two co-author pathologists reviewed tumor specimens, blinded to clinical information, at the Pathology Department of the Ioannina University Hospital. (B.A., \& P.I.) Histological typing was based on WHO classification of soft tissue tumors.

Immunostaining was performed on formalin-fixed, paraffin-embedded tissue sections using the EnVision System (DAKO Corp, Netherlands), and the monoclonal antibodies: E-cadherin (CM170B, Biocare Medical, California), beta-catenin (DBS, Menarini, Hellas) and DNA topoisomarase II-alpha (Ki-S1, DAKO). The immunohistochemical (IHC) evaluations were performed as previously described [15]. The evaluation of IHC detected expression of E-cadherin, beta-catenin and TOP $2 \alpha$ was performed by a semiquantitative method. The expression of each studied protein was considered "weak" if $1 \%$ to $20 \%$ of cancer cells were stained immunohistochemically, "moderate" if $21 \%$ to $50 \%$ were stained and "strong" if more than $50 \%$ of cancer cells stained. Nuclear and cytoplasmic staining for beta-catenin and TOP2 $\alpha$ were evaluated separately. Also, we included the intensity of staining in the classification of the each protein. Expression of each one of the proteins was investigated for association with clinical and pathological parameters, such as grade, subtype, location, grade, surgical margins, relapse, metastatic potential and overall survival. For the purposes of the correlative analysis we used $20 \%$ stained tumor cells as a cut-off level, above which, protein expression was considered positive.

\section{Statistical Analysis}

The expression of E-cadherin, beta-catenin, TOP2 $\alpha$ was investigated for associations with various pathological and clinical variables. Fisher's test and Cox models estimated hazard ratios were used to evaluate each candidate predictor. $\mathrm{P}$ values of $<0.05$ were considered statistically significant; all $\mathrm{p}$ values were two-tailed. All the dates were calculated from the day of diagnosis. Statistical analyses were performed by using the Statistical Program SPSS 14. (Chicago, IL, USA).

\section{Results}

\section{Demographics}

A total of 71 liposarcoma patients were included in the study. The median age of patients was 56 years (range 20-86), and 42 were males (59\%). Fifty-five liposarcomas were located in the extremities, and 16 were retroperitoneal. They had diverse histological liposarcoma subtypes. In the extremities and the retropetinoneum the commonest histological subtype was the well differentiated. In the extremities the commonest localization was the thigh. (Figure 1c,d)

All patients received operation by different surgeons on curative intent; surgical excision was performed in the majority (68 patients) and 3 patients underwent therapeutic limb amputation. Twenty-four patients had positive surgical margins. All patients with positive surgical margins (24) and others with marginal resection and/or high grade characteristics were given adjuvant postoperative therapy. In all, 47 patients received adjuvant radiotherapy and 11 patients adjuvant chemotherapy. Patient characteristics are presented in Table 1.

The median follow up of patients was 82 months (range 5 to 215 months). Within this follow-up period 54 patients died. Thirty eight patients (53,5\%) developed local recurrences and another 16, metastatic disease (22,5\%). Patients with retroperitoneal liposarcomas had higher local recurrence and death rates compared to those with tumor localization in the extremities (Table 1).

\section{Expression of E-cadherin, beta-catenin and topoisomerase II alpha (Table 2)}

Immunostaining for E-cadherin was negative in all cohort cases. Beta-catenin expression was documented in 15 liposarcomas (27.3\%). In 13 cases beta-catenin was weakly expressed ( $1 \%$ to $10 \%$ stained tumor cells) (Figure $1 \mathrm{~b}, \mathrm{c})$ and in 2 it was moderate (40\% and $50 \%$ of tumor cells stained) (Figure 1d). In the majority of cases beta-catenin was found located at the membrane (12/ $15)$. The intensity of beta-catenin was characterized weak and moderate in 7 and 8 sarcomas, respectively.

TOP $2 \alpha$ expression was detected in 14 cases. This was moderate in 2 extremity liposarcomas (Figure 2a) and weak in all other cases (Figure 2b). No strong TOP2 $\alpha$ 


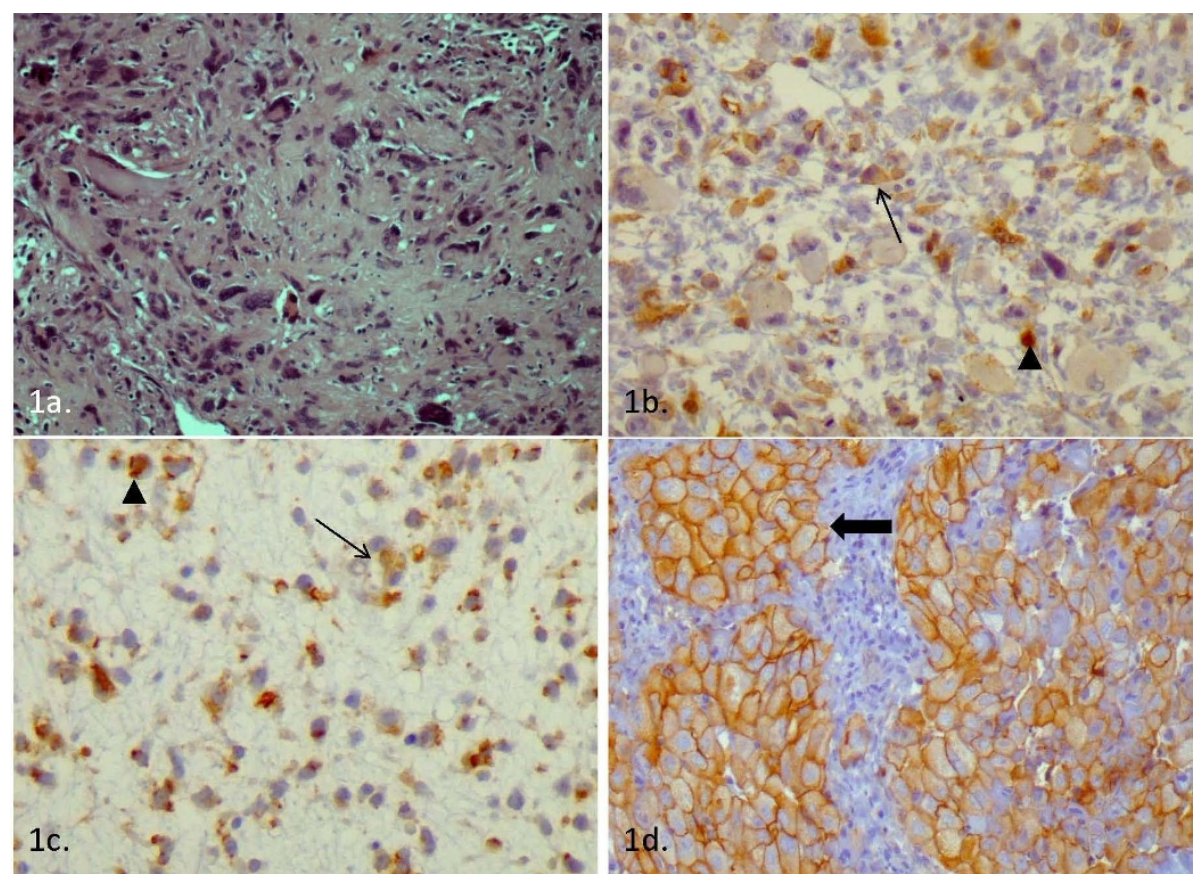

Figure 1 a) Retroperitoneal pleomorphic liposarcoma (H\&E x400) b) Weak expression of beta-catenin in pleomorphic retroperitoneum liposarcoma (< 20\% of neoplastic cells showed cytoplasmic immunoreactivity (long arrow) and < $5 \%$ nuclear immunoreactivity (short arrow) (DAB X400)). c) Weak expression of beta-catenin in extremity liposarcoma ( $<20 \%$ of neoplastic cells showed cytoplasmic immunoreactivity (long arrow) and $<5 \%$ nuclear immunoreactivity (short arrow) (DAB x400). d) Area with extensive membranous and cytoplasmic expression of beta-catenin in an extremity liposarcoma ( $<50 \%$ of neoplastic cells showed cytoplasmic and membranous immunoreactivity (long arrow) (DAB x400)).

intensity was observed. In all tumors that expressed TOP $2 \alpha$, the molecule had nuclear location. The expression of the molecules in each subgroup (extremities, retroperitoneum) is presented in Table 2 . We did not observe any statistically significant differences in the expression of beta-catenin and TOP $2 \alpha$ between the extremities and the retroperitoneum (Table 2).

\section{Clinicopathologic associations of beta-catenin and topoisomerase II alpha}

No correlation was found between expression of betacatenin or TOP $2 \alpha$ and pathological factors, such as tumor grade and histological subtype.

Beta-catenin (either membranous or nuclear expression) was not associated with local recurrences $(\mathrm{p}=$ $0.67)$, metastases $(p=0.47)$ or death $(p=0.47)$. Similarly, TOP $2 \alpha$ was not associated with clinical outcome ( $p$ values of $0.52,0.57$ and 0.78 for local recurrences, metastases and death, respectively). The cut-off level of expression in more than $20 \%$ of tumor cells was used in the pertinent analyses. However, different cut-off levels were also utilized (i.e. any expression) with no change in the results. Finally, similar results were obtained when the analyses were performed separately in extremities and retroperitoneal liposarcomas.

\section{Discussion}

Liposarcomas, is one of the commonest soft tissue sarcomas, but have been poorly investigated regarding their molecular profile. We evaluated the expression of E-cadherin, beta-catenin and TOP $2 \alpha$ in a cohort of 71 liposarcoma cases and investigated for possible associations with pathological characteristics and clinical outcome. This is, to our knowledge, the largest study that investigated E-cadherin, beta-catenin and topsiomerase II alpha in liposarcomas.

We did not detect expression of E-cadherin in our series, while $21 \%$ of cases were found to express betacatenin and 20\% TOP $2 \alpha$. We consider that absence of E-cadherin expression signifies the apparent mesenchymal origin of liposarcomas and indicates lack of any degree of epithelial differentiation in these tumors [7]. Similarly, other investigators have also reported lack of expression of E-cadherin in smaller series of liposarcomas $[7,16]$.

Regarding beta-catenin, few studies have investigated its expression in liposarcomas. $\mathrm{Ng}$ et al., found only 2 of 31 liposarcomas with increased beta-catenin [17] and Sakamoto et al., reported only cytoplasmic expression in 5 out of 12 studied cases [18]. However, none of these studies reported membranous beta-catenin expression, 
Table 1 Demographics (percentages were calculated separately in each category)

\begin{tabular}{|c|c|c|}
\hline & EXTREMITIES $(\mathrm{N}=55)$ & RETROPERITONEUM $(\mathrm{N}=16)$ \\
\hline Age: median (range) & 56 (31-80 years) & 64 (37-86 years) \\
\hline N Males (\%) & $32(58 \%)$ & 10(63\%) \\
\hline Median Size in mm (range) & $70.0(7-280)$ & $170.0(35-500)$ \\
\hline \multicolumn{3}{|l|}{ Location (\%) } \\
\hline Thigh & $27(49 \%)$ & - \\
\hline Trunk & $14(26 \%)$ & - \\
\hline Leg & $6(11 \%)$ & - \\
\hline Arm & $4(7 \%)$ & - \\
\hline Forearm & $3(5 \%)$ & - \\
\hline Hand & $1(2 \%)$ & - \\
\hline Retroperitoneum & - & $16(100 \%)$ \\
\hline \multicolumn{3}{|l|}{ Histological subtype (\%) } \\
\hline Well-differantiated liposarcomas with myxoid stroma & $32(58 \%)$ & $10(62 \%)$ \\
\hline Pleomorhic & $19(35 \%)$ & $1(7 \%)$ \\
\hline Round cell & $2(3 \%)$ & $2(12 \%)$ \\
\hline Sclerosing well-differentiated & $1(2 \%)$ & $2(12 \%)$ \\
\hline Well-differentiated Lipoma-like/adipocyticliposarcoma & $1(2 \%)$ & $1(7 \%)$ \\
\hline \multicolumn{3}{|l|}{ Grade } \\
\hline I (low) & $38(69 \%)$ & $12(75 \%)$ \\
\hline II-III (High) & $17(31 \%)$ & $4(25 \%)$ \\
\hline \multicolumn{3}{|l|}{ Type of surgery $\mathbf{N}(\%)$} \\
\hline Surgical excision & $52(94 \%)$ & $16(100 \%)$ \\
\hline Amputation & $3(6 \%)$ & $0(0 \%)$ \\
\hline \multicolumn{3}{|l|}{ Surgical Margins } \\
\hline Positive & $16(29 \%)$ & $8(50 \%)$ \\
\hline Negative & $39(71 \%)$ & $8(50 \%)$ \\
\hline \multicolumn{3}{|l|}{ Chemotherapy } \\
\hline Yes & $7(12 \%)$ & $4(25 \%)$ \\
\hline No & $48(88 \%)$ & $12(75 \%)$ \\
\hline \multicolumn{3}{|l|}{ Radiotherapy } \\
\hline Yes & $36(66 \%)$ & $11(69 \%)$ \\
\hline No & 19(34\%) & $5(31 \%)$ \\
\hline Median total radiation dose (range) & 57.0 Gy $(20.0-64.0)$ & 40.0 Gy $(40.0-64.0)$ \\
\hline
\end{tabular}

which prevailed in our series. In our study 3 cases (4.2\%) had weak expression of beta-catenin localized in the nucleus and $15 \%$ in the membrane. Although membranous beta-catenin expression was detected in only a small percentage of studied cohort this is still higher than the percentage reported in previous studies. This finding indicate that some liposarcomas may utilize at least in part beta-catenin cell to cell adhesion. Nuclear accumulation of beta-catenin is known to be involved in the Wnt signalling pathway and interplay of these two proteins have been implicated in several human carcers and in aggressive synovial sarcomas $[19,20]$. However this usually involves strong nuclear expression, which was not the case in our series [20]. A major finding in our study was the predominately membranous localization of beta-catenin, which among STS has only been described in uterine leiomyosarcomas [21]. Since, membranous beta-catenin expression was low, if any, in our liposarcomas, definite conclusion about its association with the low metastatic potential of the majority of these tumors can not be drawn $[22,23]$.

The investigation of TOP $2 \alpha$ in sarcomas has already drawn the attention of several investigators and our group [15,24]. This is due to its significant biologic role in regulating DNA metabolism and function and also because this enzyme is the target of the anthracyclin doxorubicin, which is the main chemotherapy drug with activity in sarcomas. The presence of TOP $2 \alpha$ is considered a prerequisite for anthracyclins to exert their cytotoxic effects given that the activity of these drugs correlates the nuclear content of the enzyme $[14,25]$. In addition high expression of TOP2 $\alpha$ has been profilied as an indicator of tumor aggressiveness and poor outcome in several tumor types [26]. 
Table 2 Expression of E-cadherin, $\beta$-catenin and topoisomerase Ilalpha proteins detected by IHC in $\mathbf{7 1}$ liposarcomas.

\begin{tabular}{|c|c|c|c|}
\hline & EXTREMITIES & RETROPERITONEUM & $\begin{array}{c}p \\
\text { Value }\end{array}$ \\
\hline \multicolumn{4}{|c|}{ E-Cadherin expression } \\
\hline No expression & 55 (100\%) & $16(100 \%)$ & NS \\
\hline \multicolumn{4}{|c|}{ Beta-catenin expression } \\
\hline No expression & $43(78.2 \%)$ & $13(81.2 \%)$ & NS \\
\hline $1 \%-20 \%$ & $10(18.2 \%)$ & $3(18.8 \%)$ & NS \\
\hline $21-50 \%$ & $2(3.6 \%)$ & $0(0 \%)$ & NS \\
\hline$>50 \%$ & $0(0 \%)$ & $0(0 \%)$ & NS \\
\hline \multicolumn{4}{|c|}{ Beta-catenin location } \\
\hline Membranous & 11 & 1 & 0.08 \\
\hline Nuclear & 1 & 2 & NS \\
\hline \multicolumn{4}{|c|}{ Beta Catenin intensity } \\
\hline Moderate & 7 & 1 & NS \\
\hline Weak & 5 & 2 & NS \\
\hline \multicolumn{4}{|l|}{$\begin{array}{c}\text { Topoisomerase lla } \\
\text { expression }\end{array}$} \\
\hline No expression & 45 (81.9\%) & $12(75 \%)$ & NS \\
\hline $1 \%-20 \%$ & $8(14.5 \%)$ & $4(25.0 \%)$ & NS \\
\hline $21-50 \%$ & $2(3.6 \%)$ & $0(0 \%)$ & NS \\
\hline$>50 \%$ & $0(0 \%)$ & $0(0 \%)$ & NS \\
\hline \multicolumn{4}{|l|}{$\begin{array}{l}\text { Topoisomerase lla } \\
\text { location }\end{array}$} \\
\hline Membranous & 0 & 0 & NS \\
\hline Nuclear & 10 & 4 & NS \\
\hline \multicolumn{4}{|l|}{$\begin{array}{c}\text { Topoisomerase Ila } \\
\text { intensity }\end{array}$} \\
\hline Moderate & 8 & 2 & NS \\
\hline Weak & 2 & 2 & NS \\
\hline
\end{tabular}

$P$ value is referring in the comparison between the extremities and retroperitoneum by using Fisher's test NS: non-significant ( $p>0.05)$.
It must be noted herein that, Endo et al. found DNA TOP $2 \alpha$ to be intensively expressed in cell contours in mature adipocytes and lipoblasts in all benign and malignant lipomatous tumors, which led them suggest that membranous immunostaining for TOP $2 \alpha$ might be a useful marker for diagnosing liposarcoma [27]. However we did not detect membranous localisation of TOP2 $\alpha$ but only weak nuclear expression. We consider that faint nuclear TOP $2 \alpha$ expression in our series associates well to the limited activity of anthracyclins in liposarcomas and also the relatively favourable prognosis of this sarcoma subtype which still remains dismal $[5,28]$.

\section{Conclusion}

Profiling of the expression of three studied molecules in this study elucidates to some extent some key clinical aspects of liposarcomas: lack of E-cadherin expression verifies the mesenchymal origin and weak beta-catenin and TOP $2 \alpha$ expression provide molecular reasoning of the limited aggressiveness and marginal chemosensitivity of these tumours.

\section{Acknowledgements}

We thank Dr V. Siozopoulou for critical evaluation of the manuscript.

Author details

'Department of Radiation Oncology, University loannina, Medical School, Stavrou Niarhou Av 1., 45500 Ioannina, Greece. ${ }^{2}$ Department of Pathology, University of loannina, Medical School, Ioannina, Greece, Stavrou Niarhou Av 1., 45500 loannina, Greece. ${ }^{3}$ Department of Pathology, St Savvas Cancer Hospital, Athens, Greece. ${ }^{4}$ Cancer Biobank Center, University of loannina, University Campus P.O. Box 1186, 45110 loannina, Greece.

\section{Authors' contributions}

PG: carried out material and data acquisition, did literature search, drafted the manuscript. EP: participated in the design of the study and performed the statistical analysis $\mathbf{A B}$ : carried out the immunohistochemistry studies,

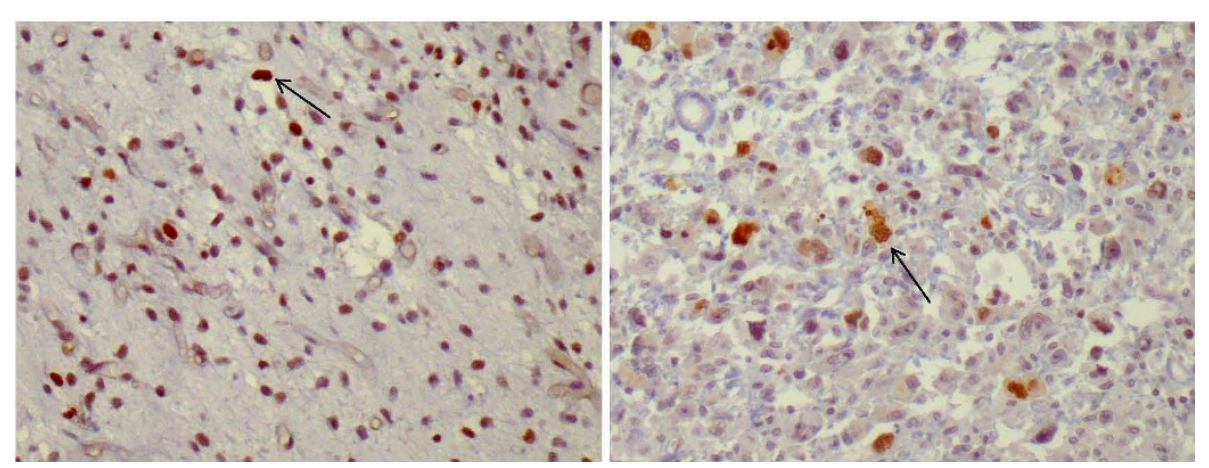

Figure 2 a) Area of extremity liposarcoma with moderate expression of topoisomerase lla (21-50\% of neoplastic cells showed nuclear immunoreactivity (arrow) (DAB X400). b) Weak expression of topoisomerase lla in extremity liposarcoma $(<20 \%$ of neoplastic cells showed nuclear immunoreactivity (arrow) (DAB X400). 
and review mmanuscript. IP: carried out the immunohistochemistry studies EB: participated in study design, data interpretation drafted and edited the manuscript. DS: carried out the immunohistochemistry studies and drafted the manuscript. NA: carried out the immunohistochemistry studies PT: proposed, designed and coordinated the study. All authors read and approved the final manuscript.

\section{Competing interests}

The authors declare that they have no competing interests.

Received: 10 May 2011 Accepted: 2 February 2012

Published: 2 February 2012

\section{References}

1. Coindre JM, Pedeutour F, Aurias A: Well-differentiated and dedifferentiated liposarcomas. Virchows Arch 2010, 456(2):167-179.

2. Clark MA, Fisher C, Judson I, Thomas JM: Soft-tissue sarcomas in adults. N Engl J Med 2005, 353(7):701-711.

3. Fletcher CD: The evolving classification of soft tissue tumours: an update based on the new WHO classification. Histopathology 2006, 48(1):3-12.

4. Reitan JB, Kaalhus O: Radiotherapy of liposarcomas. Br J Radiol 1980, 53(634):969-975

5. Karavasilis V, Seddon BM, Ashley S, Al-Muderis O, Fisher C, Judson I: Significant clinical benefit of first-line palliative chemotherapy in advanced soft-tissue sarcoma: retrospective analysis and identification of prognostic factors in 488 patients. Cancer 2008, 112(7):1585-1591.

6. Fritz B, Schubert F, Wrobel G, Schwaenen C, Wessendorf S, Nessling M, Korz C, Rieker RJ, Montgomery K, Kucherlapati R, et al: Microarray-based copy number and expression profiling in dedifferentiated and pleomorphic liposarcoma. Cancer Res 2002, 62(11):2993-2998.

7. Sato H, Hasegawa T, Abe Y, Sakai H, Hirohashi S: Expression of E-cadherin in bone and soft tissue sarcomas: a possible role in epithelial differentiation. Hum Pathol 1999, 30(11):1344-1349.

8. Moon RT: Wnt/beta-catenin pathway. SCi STKE 2005, 2005(271):cm1.

9. Nelson WJ, Nusse R: Convergence of Wnt, beta-catenin, and cadherin pathways. Science 2004, 303(5663):1483-1487.

10. Jeanes A, Gottardi CJ, Yap AS: Cadherins and cancer: how does cadherin dysfunction promote tumor progression? Oncogene 2008, 27(55):6920-6929.

11. Kase S, Sugio K, Yamazaki K, Okamoto T, Yano T, Sugimachi K: Expression of E-cadherin and beta-catenin in human non-small cell lung cancer and the clinical significance. Clin Cancer Res 2000, 6(12):4789-4796.

12. Nitiss JL: DNA topoisomerase II and its growing repertoire of biological functions. Nat Rev Cancer 2009, 9(5):327-337.

13. Esteva FJ, Hortobagyi GN: Topoisomerase II\{alpha\} amplification and anthracycline-based chemotherapy: the jury is still out. J Clin Oncol 2009, 27(21):3416-3417.

14. Nitiss JL: Targeting DNA topoisomerase II in cancer chemotherapy. Nat Rev Cancer 2009, 9(5):338-350.

15. Gogou PN, Batistatou A, Pakos EE, Apostolikas N, Stefanou D, Tsekeris PG: Ecadherin, b-catenin and topoisomerase II expression in rhabdomyosarcomas. J BUON 2009, 14(2):323-324.

16. Yoo J, Park S, Kang CS, Kang SJ, Kim BK: Expression of E-cadherin and p53 proteins in human soft tissue sarcomas. Arch Pathol Lab Med 2002, 126(1):33-38.

17. Ng TL, Gown AM, Barry TS, Cheang MC, Chan AK, Turbin DA, Hsu FD, West RB, Nielsen TO: Nuclear beta-catenin in mesenchymal tumors. Mod Pathol 2005, 18(1):68-74

18. Sakamoto A, Oda Y, Adachi T, Saito T, Tamiya S, Iwamoto $Y$, Tsuneyoshi M: Beta-catenin accumulation and gene mutation in exon 3 in dedifferentiated liposarcoma and malignant fibrous histiocytoma. Arch Pathol Lab Med 2002, 126(9):1071-1078.

19. Clevers $\mathrm{H}: \mathrm{Wnt} /$ beta-catenin signaling in development and disease. Cell 2006, 127(3):469-480

20. Hasegawa T, Yokoyama R, Matsuno Y, Shimoda T, Hirohashi S: Prognostic significance of histologic grade and nuclear expression of beta-catenin in synovial sarcoma. Hum Pathol 2001, 32(3):257-263.

21. Abeler VM, Royne O, Thoresen S, Danielsen HE, Nesland JM, Kristensen GB: Uterine sarcomas in Norway. A histopathological and prognostic survey of a total population from 1970 to 2000 including 419 patients. Histopathology 2009, 54(3):355-364.
22. Hsu PK, Li AF, Wang YC, Hsieh CC, Huang MH, Hsu WH, Hsu HS: Reduced membranous beta-catenin protein expression is associated with metastasis and poor prognosis in squamous cell carcinoma of the esophagus. J Thorac Cardiovasc Surg 2008, 135(5):1029-1035.

23. Rosen DG, Zhang Z, Chang B, Wang X, Lin E, Liu J: Low membranous expression of beta-catenin and high mitotic count predict poor prognosis in endometrioid carcinoma of the ovary. Mod Pathol 2010, 23(1):113-122.

24. Gogou PN, Batistatou A, Pakos EE, Apostolikas N, Stefanou D, Tsekeris PG: Expression of E-cadherin, beta-catenin and topoisomerase llalpha in leiomyosarcomas. Clin Transl Oncol 2009, 11(8):548-551.

25. Chikamori K, Grozav AG, Kozuki T, Grabowski D, Ganapathi R, Ganapathi MK: DNA Topoisomerase II Enzymes as Molecular Targets for Cancer Chemotherapy. Curr Cancer Drug Targets 2010.

26. Rody A, Karn T, Ruckhaberle E, Muller V, Gehrmann M, Solbach C, Ahr A, Gatje R, Holtrich U, Kaufmann M: Gene expression of topoisomerase II alpha (TOP2A) by microarray analysis is highly prognostic in estrogen receptor (ER) positive breast cancer. Breast Cancer Res Treat 2009. 113(3):457-466.

27. Endo H, Hirokawa M, Ishimaru N, Tanaka Y, Yamashita M, Sakaki M, Hayashi Y, Sano T: Unique cell membrane expression of topoisomerase-II alpha as a useful diagnostic marker of liposarcoma. Pathol Int 2004, 54(3):145-150.

28. Krikelis $D$, Judson I: Role of chemotherapy in the management of soft tissue sarcomas. Expert Rev Anticancer Ther 2010, 10(2):249-260.

\section{doi:10.1186/1477-7819-10-28}

Cite this article as: Gogou et al: Clinicopathologic study of E-cadherin/ beta-catenin complex, and topoisomerase-II in a series of 71 liposarcoma cases. World Journal of Surgical Oncology 2012 10:28.

\section{Submit your next manuscript to BioMed Central and take full advantage of:}

- Convenient online submission

- Thorough peer review

- No space constraints or color figure charges

- Immediate publication on acceptance

- Inclusion in PubMed, CAS, Scopus and Google Scholar

- Research which is freely available for redistribution 